\title{
A Methodology for an Integrated Approach for Seismic and Energy Refurbishment of Historic Buildings in Mediterranean Area
}

\author{
Angela Moschella 1,*(D), Antonio Gagliano ${ }^{2}$, Alessandro Lo Faro ${ }^{1}$ (D) , Attilio Mondello ${ }^{1}$ (D), \\ Angelo Salemi ${ }^{1}$ and Giulia Sanfilippo ${ }^{1}$ \\ 1 Department of Civil Engineering and Architecture, University of Catania, Via Santa Sofia 64, \\ 95123 Catania, Italy; alessandro.lofaro@darc.unict.it (A.L.F.); amondello@darc.unict.it (A.M.); \\ angelo.salemi@darc.unict.it (A.S.); giulia.sanfilippo@darc.unict.it (G.S.) \\ 2 Department of Electric, Electronic and Computer Engineering, University of Catania, Viale A. Doria 6, \\ 95125 Catania, Italy; agagliano@dii.unict.it \\ * Correspondence: angela.moschella@darc.unict.it; Tel.: +39-095-738-2532
}

Received: 28 May 2018; Accepted: 10 July 2018; Published: 13 July 2018

\begin{abstract}
Energy savings and seismic risk mitigation are the main issues regarding the refurbishment of traditional buildings. Referring to historic buildings, we have to take into account, as design requirements, the cultural sustainability, which means the respects of the cultural value of the built heritage. Therefore, for historic buildings is not acceptable to adopt the conventional design choices applied to newer buildings on energy efficiency and seismic risk mitigation. Generally, the design on the built heritage requires a careful cognitive phase for firstly to identify the performance deficits and subsequently to define which actions are compatible with the cultural value of each building, according to a "case by case" approach. In Italy, specific guidelines have been elaborated on cultural heritage but such guidelines are not integrated into a single methodological process. This paper, through the study of two historic buildings, aims to identify the relationship between the two specialisms, seismic and energy, within an integrated approach. As a result, this study proposes an innovation process characterized by the integration of these two protocols within the cognitive phase and, especially in the pre-diagnosis phase; this phase is identified in the standard diagnosis (Energy approach) and in the LV2 knowledge (Seismic empirical approach).
\end{abstract}

Keywords: historic massive envelope; cultural value; energy performances; damage mechanisms; pre-diagnostic process; seismic improvement; energy savings; Eastern Sicily

\section{Introduction}

Built heritage tells of the close relationship between man and environmental resources; this has defined the image of our historic cities in the material and formal aspects. According to ISTAT data (Italian National Institute of Statistics), the residential historic buildings (built before 1919) account for $19.2 \%$ of the Italian built heritage. Considering the masonry buildings, this percentage increases to $61.5 \%$, if we think that this type of construction had also been used up to the 1950 s.

Every building is an open system that interacts with its environment continuously. We refer to the climatic conditions, which, in the past, determined the shape of the urban fabric and the effects of earthquakes. Within the Mediterranean climate environment, we have directed our attention to Catania, whose seismicity degree is very high; in fact, the city was rebuilt after the violent earthquake of 1693 . Its historic centre is therefore made up of massive buildings, with a loadbearing masonry structure.

Traditional buildings are characterized by vertical opaque closures with high thermal transmittance $(\mathrm{U})$, which do not guarantee a good energy performance in the winter season [1]. 
The current Italian legislation for energy renovation measures requires significantly lower U-values than the existing ones. Moreover, the U-values for the massive vertical closures are calculated according to the UNI/TS 11300-1 [2]. Recent studies have shown how the values calculated in this way are higher than those measured in situ [3-5]. Any energy refurbishment strategy must respect the cultural value of historic buildings, if applied to them. This value also regards the surfaces of the envelope. Therefore, it is necessary to rethink the role of insulation and its congruence with these surfaces. For historic buildings that are located in the most severe climatic zones (winter), energy renovation interventions provide for thermal insulation on the inner side of the wall panel [6,7]. For those belonging to the Mediterranean climate, however, this intervention is not advisable because it does not allow for the exploitation of the thermal inertia of massive vertical closures [8]. Therefore, even if we did not consider the cultural value of the buildings that characterize the historic centres of Mediterranean cities, many studies propose to change strategy and focus on the role of the thermal inertia of the wall structures $[9,10]$. It determines time lag and attenuation of the thermal wave, so the effects of thermal forcing, especially in the summer, can be mitigated by night-time ventilation. In this way, the ENEA-MiSE research report, based on the Program Agreement between the ENEA (Italian National Agency for New Technologies, Energy and Sustainable Economic Development) and the MiSE (Italian Ministry of Economic Development), has classified the Italian municipalities according to an index of summer climatic severity. In this ranking Catania has the highest index in the scale from A to E (Figure 1) [11].

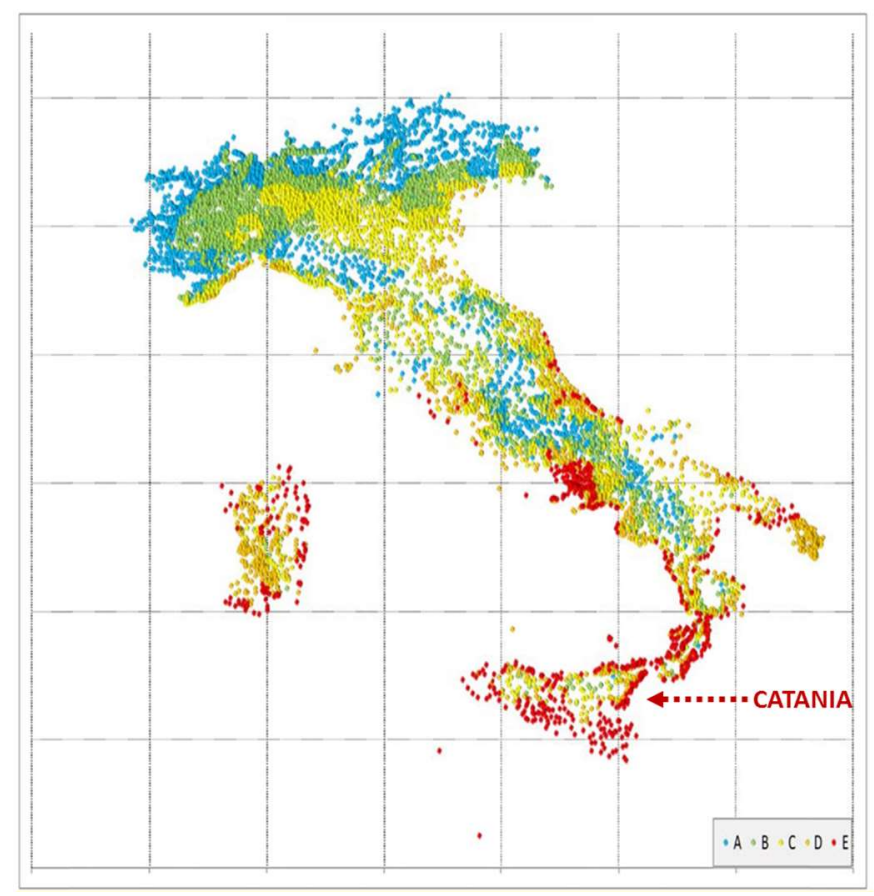

Figure 1. National geographical distribution of summer classes [11].

As for the remaining part of the external envelope, interventions that can also be used in buildings without cultural value may be considered but it will be necessary to decide on a "case-by-case" basis.

Current Italian legislation defines limit values of thermal transmittance and for the certification of the energy performance class refers to a steady-state calculation model that for massive buildings tends to overestimate the energy needs [12].

Therefore, the improvement of energy performance of historic buildings is a complex issue and should be treated according to a systemic approach; based on this awareness, Battisti asserts that, "a formulation of guidelines for improving the energy efficiency of this historical heritage was created, taking place through the integration of skills and information of various kinds. Superintendents and 
University Professors in the disciplines of Restoration, Plant and the Technology of Architecture were thus brought to a working table, with attention focusing on assessments not only of how much is consumed but also of the how and the why" [13]. These 2015 "Guidelines for the improvement of energy efficiency in cultural heritage" define distinct levels of energy diagnosis of historic buildings (Table 1), as well as eligible design actions but only in relation to the cultural value of each single technical element [14].

Table 1. Comparison between the three levels of energy diagnosis. "ORE": Energy Saving Opportunities (From Table 7 of energy guidelines 2015).

\begin{tabular}{|c|c|c|c|}
\hline Type & Features & Results & Timing \\
\hline $\begin{array}{l}\text { Level I: } \\
\text { light }\end{array}$ & $\begin{array}{l}\text { Inspection of the building object } \\
\text { of diagnosis to visually inspect } \\
\text { each of the energy systems } \\
\text { and/or subsystems. }\end{array}$ & $\begin{array}{l}\text { Evaluation of energy and economic savings } \\
\text { potential based on the indication of the } \\
\text { "ORE" at low investment cost. } \\
\text { Qualitative list of action scenarios. } \\
\text { Indications for a subsequent level II or } \\
\text { III analysis. }\end{array}$ & Few days \\
\hline $\begin{array}{l}\text { Level II: } \\
\text { standard }\end{array}$ & $\begin{array}{l}\text { Energy analysis of plant systems } \\
\text { with steady-state calculation } \\
\text { models. Small measurements. }\end{array}$ & $\begin{array}{l}\text { Indication of the "ORE" and the action } \\
\text { scenarios to be applied to the building } \\
\text { through energy, economic and } \\
\text { multi-criteria analysis. }\end{array}$ & Few weeks \\
\hline $\begin{array}{l}\text { Level III: } \\
\text { detailed }\end{array}$ & $\begin{array}{l}\text { Energy analysis of plant systems } \\
\text { with dynamic calculation models. } \\
\text { Detailed measurements on } \\
\text { the components. }\end{array}$ & $\begin{array}{c}\text { Evaluation of primary energy consumption } \\
\text { divided by use function, energy vector and } \\
\text { profiles of use. } \\
\text { Accurate indication of the "ORE" and } \\
\text { action scenarios, to be applied to the } \\
\text { building through energy, economic and } \\
\text { multi-criteria analysis. } \\
\text { Definition of interactions between the } \\
\text { different scenarios. }\end{array}$ & $\begin{array}{l}\text { Weeks or } \\
\text { months }\end{array}$ \\
\hline
\end{tabular}

The same problems arise when one thinks in terms of security needs. The design action cannot be undertaken in terms of upgrading, as in the case of modern constructions, when we refer to built heritage.

Indeed, a new technical-scientific awareness for the seismic safety of the architectural heritage developed between the 1980s and 1990s. In 1986, the "Raccomandazioni per gli interventi sul patrimonio monumentale a tipologia specialistica in zone sismiche" were published. This chart identified possible solutions to resolve the conflict between conservation and protection against the seismic risk of historical architecture. In the same years, reliable studies of the theory of structures confirmed the possibility of improving (rather than adapting) the mechanical performance of historic buildings against seismic stresses, following the "good rules of art" (as suggested by Giuffrè, Doglioni, Di Pasquale and the Italian research groups of GNDT-National Group for defence against Earthquakes) [15-17]. It has been demonstrated that the masonry collapses due to instability rather than due to the reduction of the resistant sections in case of earthquake and it works better if the stone elements are well organized and bonded with high-quality mortar and if the links, between the walls and between walls and floors (traditionally made of metal elements- "bolzoni" - to counter the pushing actions), or the roofing beams are effective. This led to the common belief that, for historic buildings, simple corrective and non-invasive actions were to be favoured, rather than adaptations to the seismic regulations about the modern built heritage. These technical and cultural issues influenced the first draft of the "Codes of Practice" and the kinematic analysis for each macro-element of the buildings simplified in abacuses [17]. These abacuses were made to attenuate the separation between "tradition and practical and theoretical knowledge" [18]. Subsequently, these procedural indications were perfected and disseminated by the Italian "Guidelines for the Evaluation and Reduction of 
Seismic Risk of Cultural Heritage" of 2011 [19,20]. This approach is based on the knowledge of the building, on its intrinsic vulnerabilities (construction techniques) or on the vulnerabilities induced by subsequent works. Indeed, the kinematic analysis is subordinated to the empirical reading of the possible damage mechanisms that can be activated in the macroelements of traditional buildings. This reading is based on in-depth and meditated experimental knowledge of a large series of buildings disrupted by the earthquakes in the last twenty years [21]. The aforementioned 2011 Guidelines offer a tool to set up a reasoned cognitive analysis, both at the architectural level (at the scale of the single building) and at the urban scale in order to plan seismic prevention or "a planned reduction of risks" (Table 2) [19].

Table 2. Summary table for the assessment of seismic capacity (From Table 7.1 of 2011 Guidelines).

\begin{tabular}{ccc}
\hline \multicolumn{3}{c}{ Design of Seismic Improvement Actions } \\
\hline Aim & Minimum Assessment Level & Calculation Models \\
\hline $\begin{array}{c}\text { Local or repair actions on limited } \\
\text { areas of the building. }\end{array}$ & LV2 & $\begin{array}{c}\text { Local damage mechanisms on } \\
\text { single parts of the building. }\end{array}$ \\
\hline $\begin{array}{c}\text { Improvement actions involving } \\
\text { the seismic behaviour of the whole } \\
\text { building. }\end{array}$ & LV3 & $\begin{array}{c}\text { Exhaustive local damage } \\
\text { mechanisms. } \\
\text { Global model }\end{array}$ \\
\hline
\end{tabular}

Despite the existence of three levels of investigation, the 2011 Italian Guidelines suggest using the global calculation models only as the last accurate level of in-depth analysis and as calculation of the final design (LV3). In the preliminary phase (that we want to highlight in this study), for the choice of possible design solutions to be applied, the Guidelines require consideration into the possible damage mechanisms at the local level of the building's macroelements (LV2).

It is also important to underline that the first level of in-depth analysis (LV1) proposed by the Guidelines was strongly disapproved and considered unreliable by several studies [21]. Indeed, the LV1 level on a territorial scale provides for a global shear check that underestimates real risks. This global shear check does not consider the rollover mechanisms and the so-called "non-quantifiable" risks (such as detachment of decorations, decays phenomena, plants) [21].

We can therefore observe that both specialisms (energy and seismic fields) have elaborated their own guidelines autonomously and not integrated into a single methodological process; however, both disciplines require a preliminary knowledge phase of the building.

Currently, there is a lack of researches that follow an integrated approach between energy and seismic refurbishment. Some studies analyse the complexity of energy refurbishment applied to the built heritage, where it must coordinate cost-effective and architecturally compatible actions, according to the European methodology of cost optimality [22]. Other researches underline that structural safety and energy performance are some of the main aspects to be taken into consideration for built heritage, by respecting, first of all, its cultural value. The interaction between structural and energetic issues is obtained through a methodological approach for building diagnostic activities that optimize costs and execution time of the in-situ tests [23].

Recently, there has been an increase in researchers, who have proposed at least a multidisciplinary approach. The European Project for Safer and Energy Efficient Buildings proposes a multi-benefit approach that is provided by a closer integration between energy and non-energy related benefits [24]. This project combines different pre-fabricated elements in an integrated system that enables the achievement of high performance in terms of energy requirements, structural safety and social sustainability. Other authors have pointed out the common practices for buildings with reinforced concrete structures, in Italy and Romania and described some key combined renovation interventions as well as advantages and perspectives of an integrated renovation approach [25].

The design of structural and energy retrofit interventions planned for historic load-bearing masonry buildings has been proposed for the town of Enna [26]. To understand the gap between the 
current state of the buildings and Italian standards, structural and energy audits had been undertaken. Therefore, suitable interventions, which take into account the site characteristics and the energy and seismic risk class, are proposed. This multidisciplinary approach was applied in an experimental study for the energy and structural upgrade methodology of an existing school building in the north-east of Italy. The methodology followed is based on the International Energy Agency-Energy in Buildings and Communities Programme (IEA-EBC) Annex 56 project guidelines [27].

The study presented here deals with these two issues. Thereby, two case studies on two traditional buildings, namely Nicotra and Marano House, representative of the historical centre of Catania, have been developed. This paper discusses the cognitive phase and in particular the pre-diagnostic phase; in this, qualitative simulation methods are used: steady-state method for the energy evaluation and empirical method for the seismic aspects.

Quantitative (dynamic and kinematic or global) methods of calculation do not fall within the objective of this study, which is instead to define how to integrate the two different analysis processes.

\section{Materials and Methods}

According to a consolidated methodology, any design regarding the built (both in terms of energy improvement and that of seismic) is preceded by a cognitive process in which there are many observers representing the different disciplines involved. Each of them makes its own disciplinary apparatus available and performs a reading of the building (understood as a "stone document") and of the relationships that it has linked with the built environment. About the buildings, we have to define the historical-architectural value and describe the constructive history, the architectural and geometrical configuration, the environmental and technological systems (in the physical configuration and in the current performances) and the degradation processes in progress.

By setting up these levels of description, we can thus obtain exhaustive knowledge of the building system, in terms of performances deriving from the specific classes of needs (safety, wellness, etc.) and cultural constraints necessary to validate the design choices. Therefore, the diagnosis and the value judgment about the building represent the last step of the cognitive process and the starting point to validate the design [28].

It should be noted that the complete knowledge of the building is reached through successive phases: pre-diagnosis, design of ND tests and diagnosis (Figure 2). In particular, pre-diagnosis corresponds to a first level of knowledge; it lays the foundations for defining operative tools and analytical methods to validate hypotheses on performance deficits and, at the same time, allows for the definition of a scenario of possible actions.

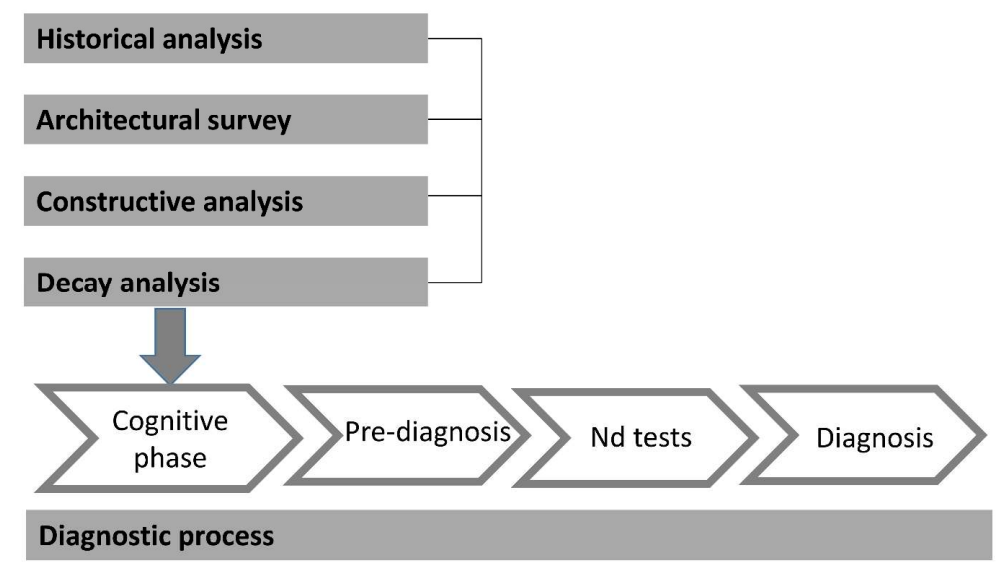

Figure 2. General methodology for the refurbishment of built heritage. 
In the present case, we have analysed the two protocols, reported in Tables 1 and 2 and for each protocol the analytical activities responding to a level of basic-qualitative knowledge to define the pre-diagnostic phase were identified.

The "standard" energy diagnosis and the "empirical" structural analysis methods (Figure 3) have been identified as qualitative approaches, which have to be coordinated by the architect considering the complexity of the historic built.

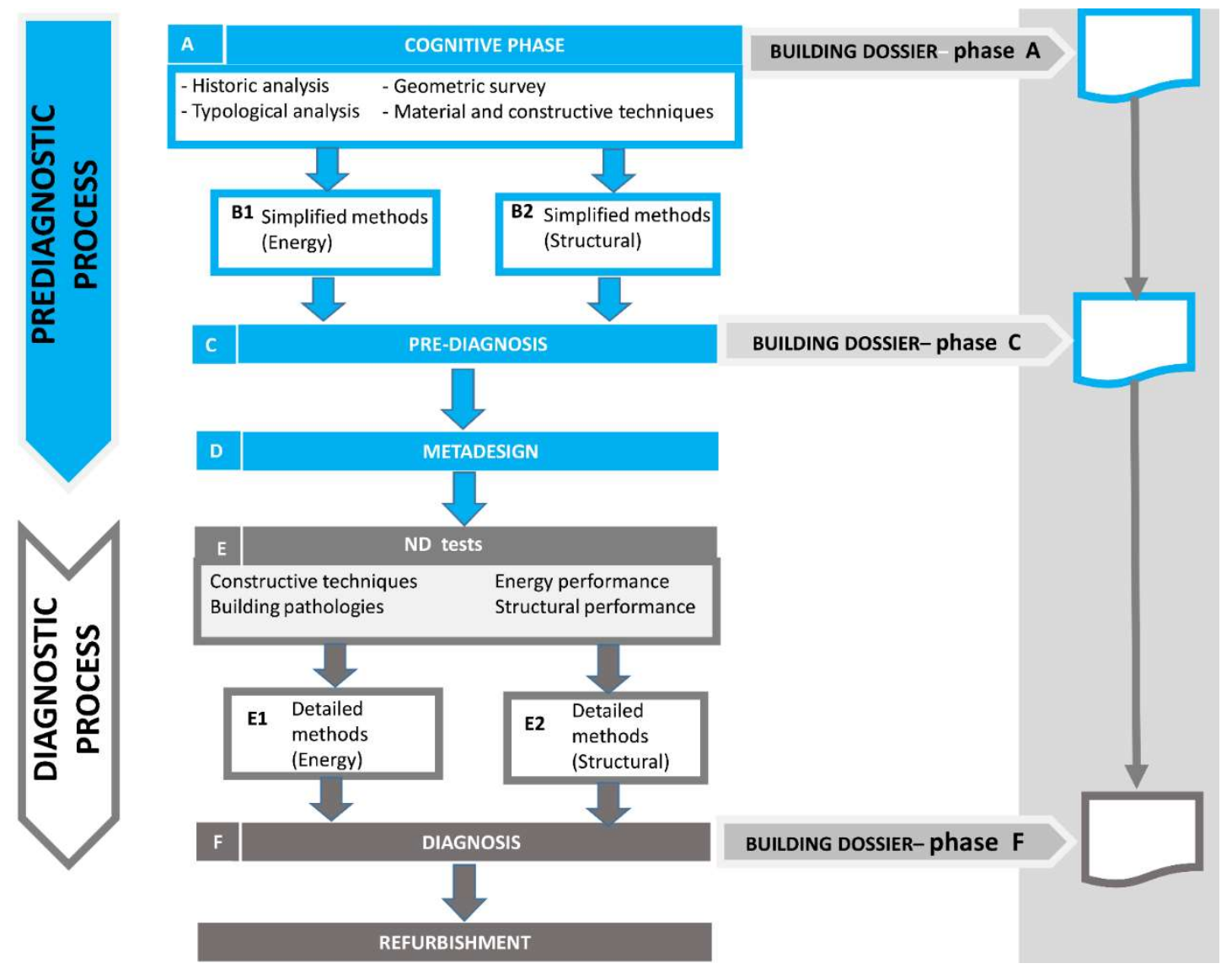

Figure 3. Methodology proposed for the energy and seismic refurbishment (highlighted the relationships between the different specialized disciplines).

A methodology characterized by an integrated approach is therefore proposed. Such methodology allows us to simplify the management of the diagnostic phase, which inevitably must be followed by specific technical skills: in this case, building physics engineers (to evaluate the energy performances) and structural engineers (to evaluate the mechanical performances).

Therefore, the study was conducted following three phases: the first and second ones represent the cognitive phases, while the third one deals with the guidelines for refurbishment under the constraint to respect the cultural value. We reiterate that, even after a pre-diagnosis, any design actions to be validated should be confirmed using quantitative methods.

- First phase (A): study from the typological, geometric-spatial and technical-constructive point of view.

- Second phase (B): evaluation of the energy performances and qualitative seismic vulnerability, according to Standard diagnosis (Level II) of the Italian "Guidelines for the improvement of energy efficiency in cultural heritage" of 2015 [14,29,30] and the 2011 Italian "Guidelines for the Evaluation and Reduction of Seismic Risk of Cultural Heritage" and their LV2-Knowledge level [19]. 
- Third phase (C): definition of the scenario of the actions that could guarantee an improvement of the energy performances and the punctual behaviour of the structures, highlighting which vulnerabilities should be corrected, while respecting the cultural values of the building.

\section{The Case Studies}

\subsection{Typological, Geometric and Formal Aspects}

In 1888, the city plan of Catania, drawn up by the engineer B. Gentile Cusa, provided for an extension towards the east, set on road axes of expansion of the urban centre towards the coast. The research took account of two different buildings in via Umberto I, the first of the executed axes. Nicotra House and Marano House represent emblematic cases of a considerable sample of residential buildings built between the 19th and the early 20th century in Catania. These buildings were designed by two protagonists of the keen cultural and entrepreneurial activity of the period: Nicotra House by Carlo Sada and Marano House by Tommaso Malerba.

The architect Carlo Sada (Milano, 1849-Catania, 1924), considered among the best professionals in the city at the time, designed Nicotra House for Mr. Francesco Nicotra between 1898 and 1901 [31] (Figure 4a). Marano House was designed in 1907 by the engineer Tommaso Malerba (Catania, 1866-1962), a local exponent of the modernism art movement (Figure 4b) [32,33].

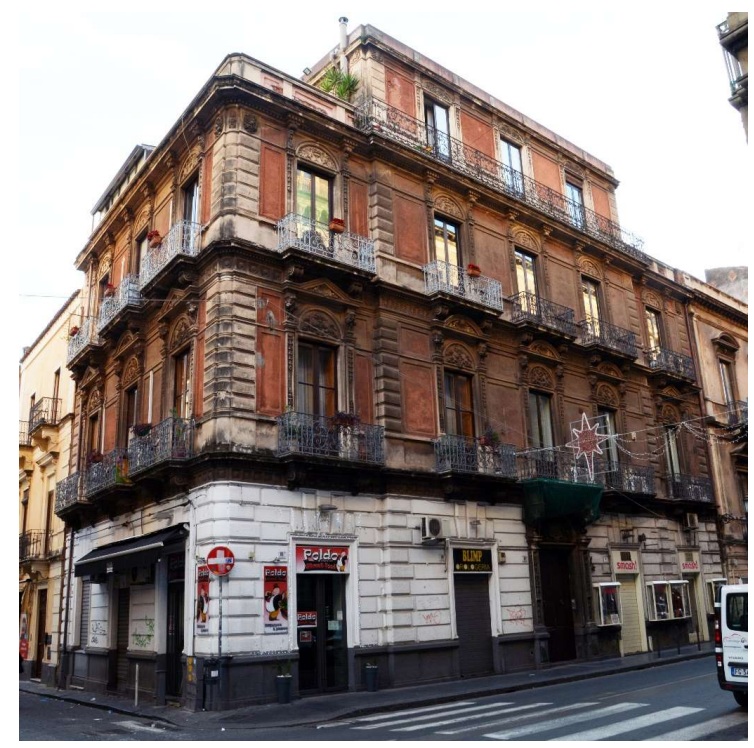

(a)

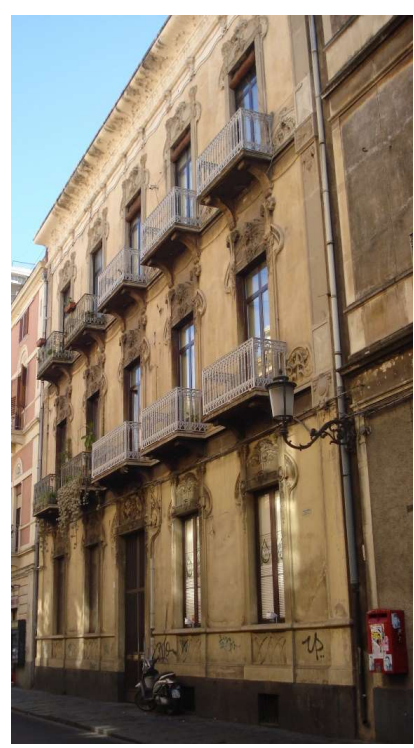

(b)

Figure 4. View of the external fronts. (a) Nicotra House; (b) Marano House.

Regarding the urban fabric, the first case study is in a corner plot and the second in a landlocked plot. Indeed, Nicotra House is located in the first part of via Umberto I, at the corner with via Grotte Bianche (Figure 5a), while Marano House is in the easternmost part of the road axis (Figure 5b). Both buildings belong to the building type of "in line house," with a central staircase in an almost barycentre position [34]. 


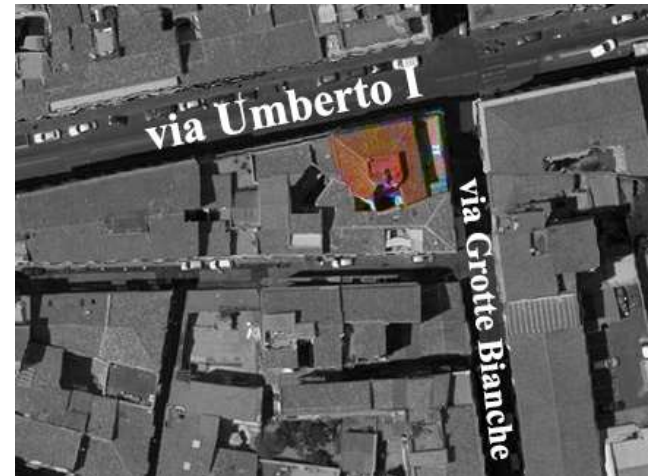

(a)

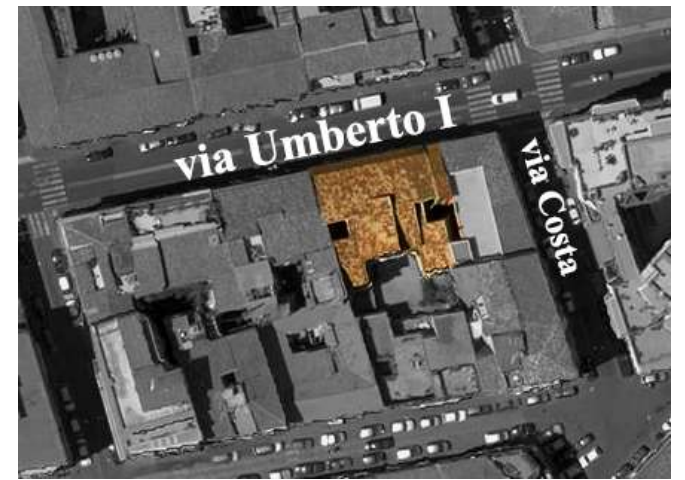

(b)

Figure 5. Localization of the cases study: (a) Nicotra House; (b) Marano House.

The planimetric layout of the two residences differs only from the number of floors (four in Nicotra House and three in Marano House) and the former use of the ground floors: with commercial shops and mezzanines-warehouse in the first case and residential use in the typical "rez de chaussée" of the second case. Above, there are two apartments per floor with mezzanine floors. In these apartments, the living area overlooks the public streets while the other rooms and the mezzanines are at the back (Figure 6). The façades of via Umberto I are oriented to the north, while the west and south fronts form a small courtyard.

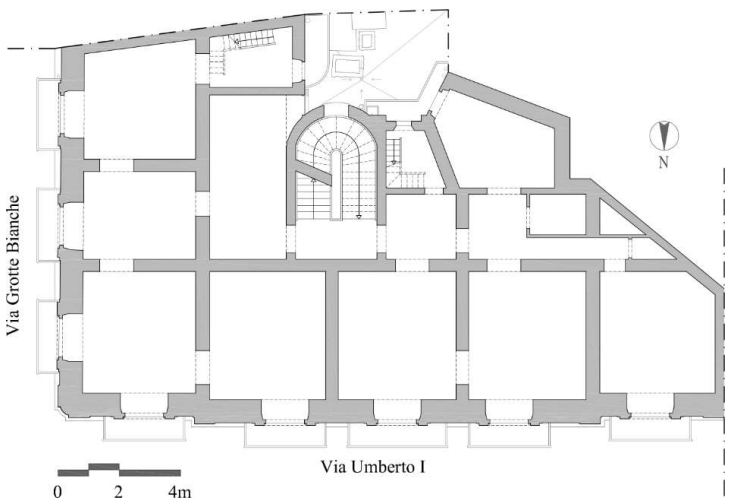

(a)

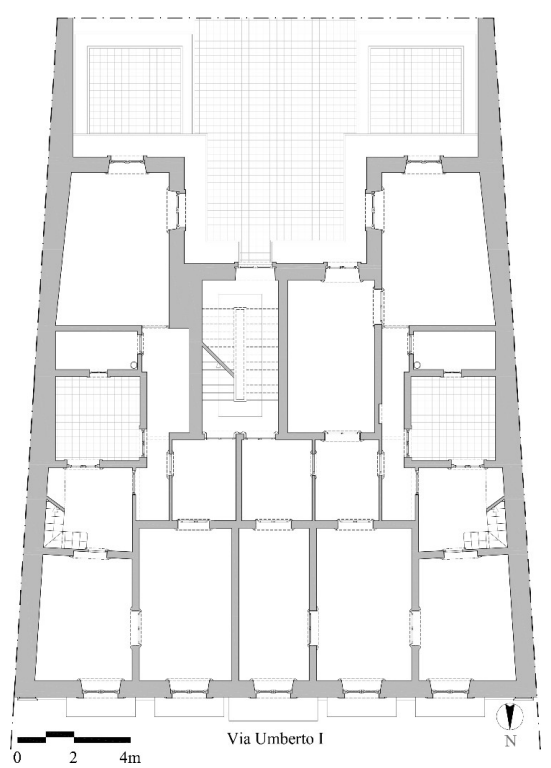

(b)

Figure 6. Geometric survey: first floor plan. (a) Nicotra House; (b) Marano House.

In Nicotra House, the main front has an axis of central symmetry, marked by the entrance portal with an upper tribune. The formal composition is rather monotonous and strict but it acquires character only in the ashlar of the ground floor, in the corner, in the decorations of the friezes of the stringcourses and the cornice and in the fluid and complex iron railings. The main front also has a central part with four floors and emerges from the rest of the façade with a slight overhang. The lateral part has three elevations and it is defined above by terraces. The roof of the central part is a hip end roof, while in correspondence with the stairwell we find a terrace not foreseen in the original project and, presumably, it is to be classified as a historicized addition (Figures $7 \mathrm{a}$ and $8 \mathrm{a}$ ). 


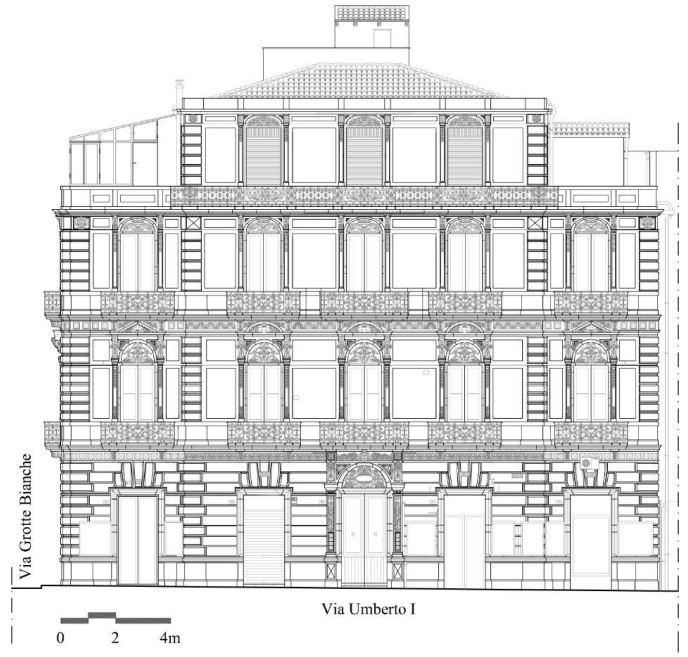

(a)

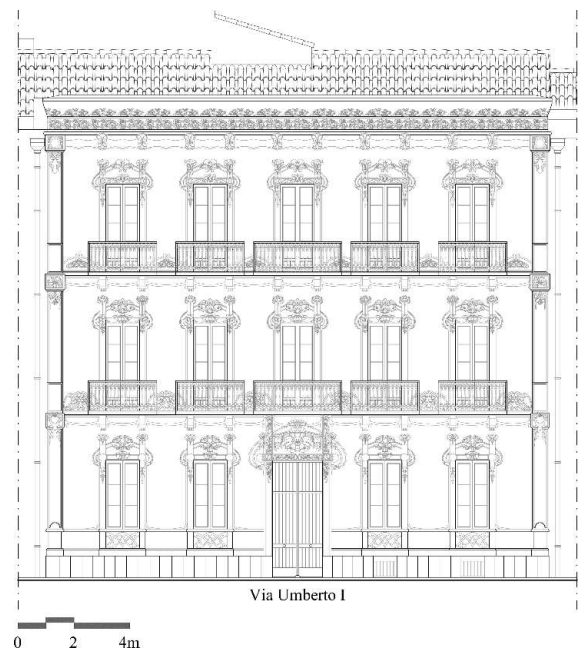

(b)

Figure 7. Geometric survey: elevations. (a) Nicotra House; (b) Marano House.

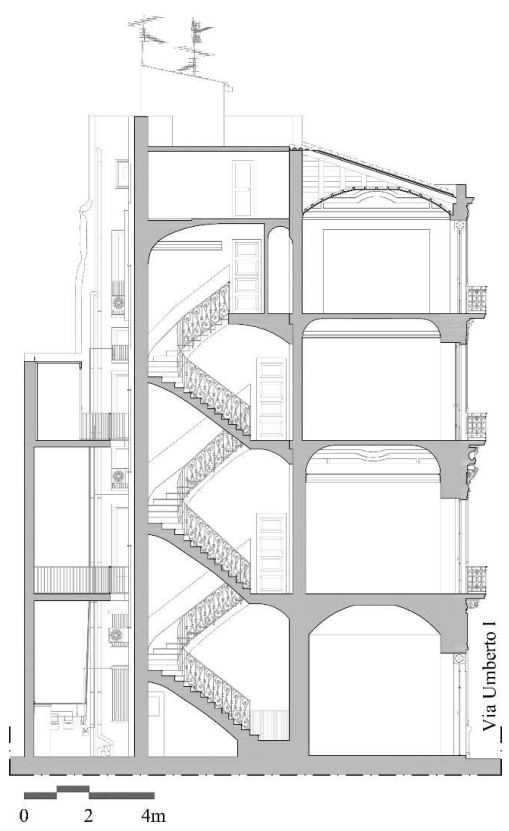

(a)

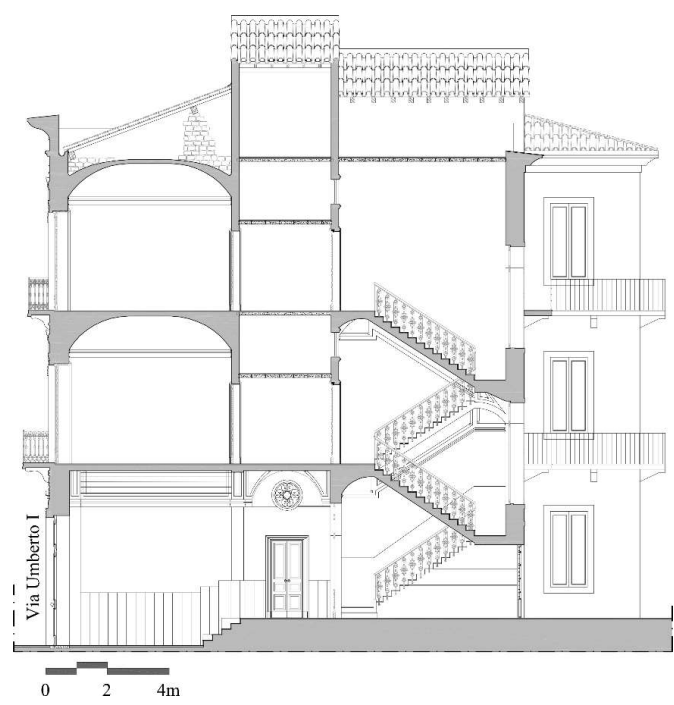

(b)

Figure 8. Geometric survey: cross sections. (a) Nicotra House; (b) Marano House.

Marano House also has a façade characterized by a clear central symmetry. Unlike Nicotra House, the rigid geometrical settings are lessened and converted into the typical Art Nouveau language, with sinuous phytomorphic bands and masks with female faces in the decorations of the jambs, stringcourses and cornices [33]. A pitched roof (Figures $7 \mathrm{~b}$ and $8 \mathrm{~b}$ ) completes the last floor.

\subsection{Building Techniques}

The vertical envelope of Nicotra House is formed by bearing masonry in roughly basalt blocks and listed pressed bricks, on mortar beds of lime with volcanic aggregates (with an average thickness of $80 \mathrm{~cm}$ in the perimeter walls and $30 \mathrm{~cm}$ for the internal partitions); the masonry of Marano House is in roughly basalt blocks (with thickness of $60 \mathrm{~cm}$ in the perimeter ones and $25 \mathrm{~cm}$ for the internal partitions). 
The horizontal structures of Nicotra and Marano Houses are characterized on the ground floor by concrete vaults, in pumice stone and gypsum mortar, while those of the intermediate floors consist of floors with NP iron beams with concrete filling in pumice and gypsum mortar. The rooms on the top floor are defined above by "camorcanna" vaults in Nicotra House and by pavilion vaults, in pumice stone and gypsum mortar in Marano House (in Marano House, on the top floor the service rooms are covered by floors with NP iron beams).

In Nicotra House, the pitched roof has a supporting structure with rafters placed on a recently reinforced concrete curb while in Marano House the pitched roof is with purlins on walls (Figures 9 and 10). The discontinuous surface of the roof is formed with Sicilian tiles.

The external fronts of Nicotra House have a decorative limestone apparatus (frames, string courses, pilasters, entrance portal) embellished with floral decorations that are found on the tympana and in the archivolts of the first second and third level (Figure 11a). Instead, in Marano House the liberty decorations are made of artificial stone (in lime mortar with volcanic aggregates and marble dust; the finish in lime mortar with lime aggregates and marble dust) through a moulding process. (Figure 11b).

The external plasters are in lime mortar with "ghiara," a volcanic aggregate no longer extracted from the local caves (Nicotra House) and in coloured mortar (Marano House). The door-window casings have a chestnut wood frame and simple glass $(3 \mathrm{~mm}$ ) which occupies only $2 / 3$ of the door surface. As regards the shieldings, no external shielding is detected. In Nicotra House, there are "Malta-type" wooden wickets; in the Malta shielding the movable shutter is tied by a hinge to the movable frame and it covers up only the panes. Marano House have "Palermo-type" wooden shieldings; in these shieldings the shutter is tied to the fixed frame and covers up the whole casing [35].

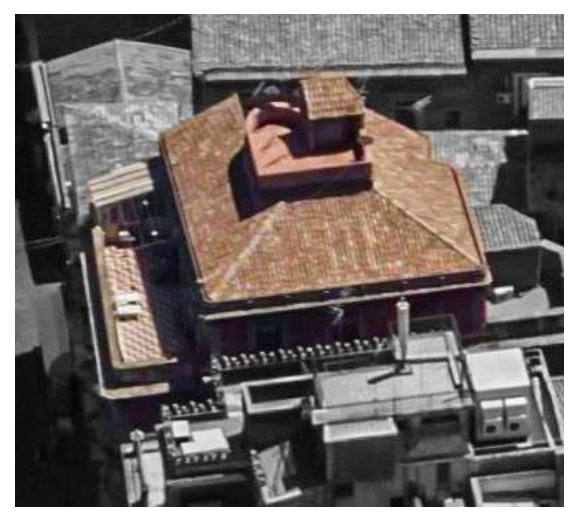

(a)

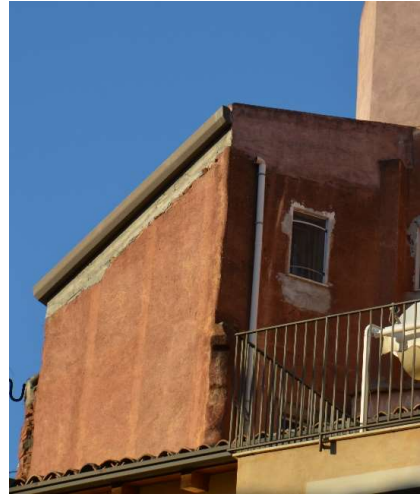

(b)

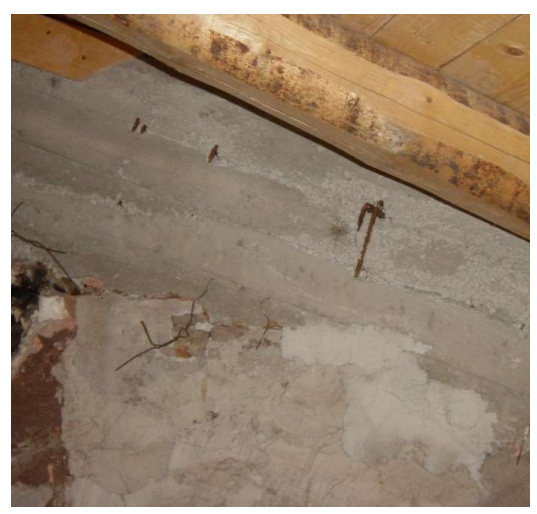

(c)

Figure 9. Roof solution in Nicotra House. (a) Overall view; (b,c) reinforced concrete summit curb.

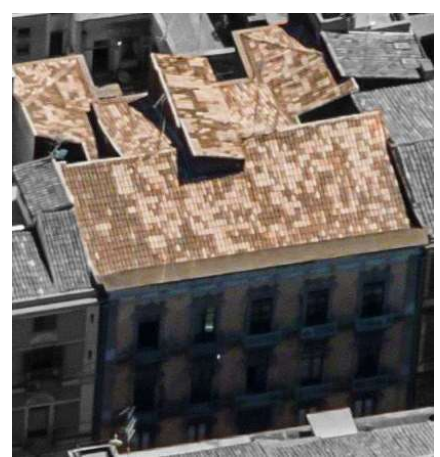

(a)

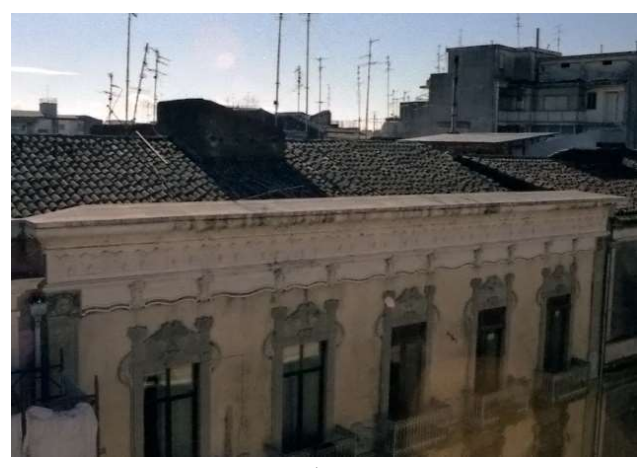

(b)

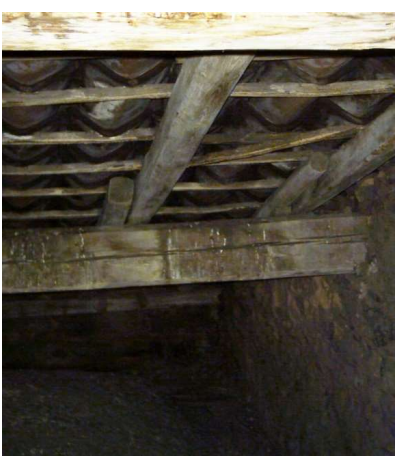

(c)

Figure 10. Roof solution in Marano House. (a,b) Overall view; (c) inner view. 


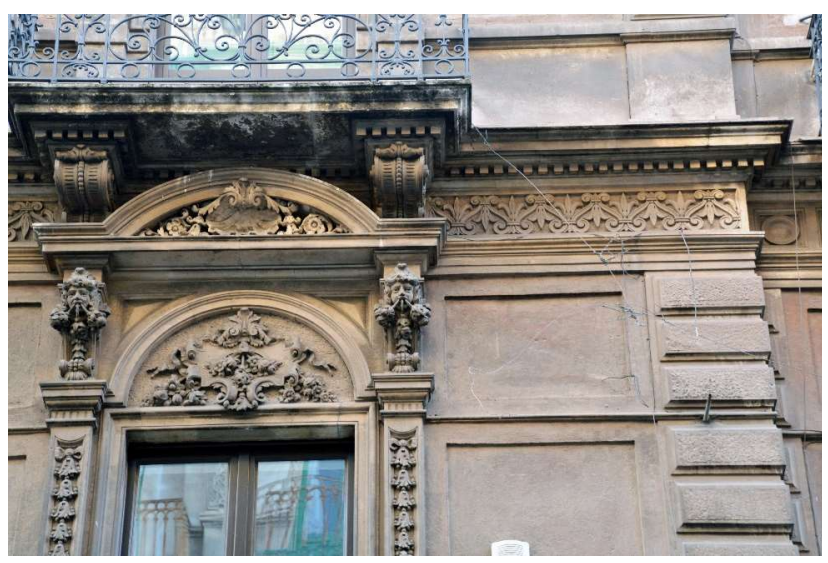

(a)

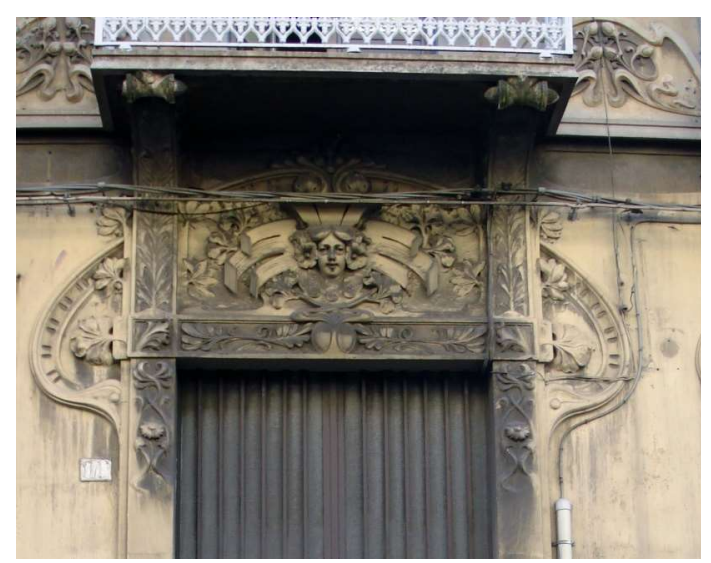

(b)

Figure 11. Detail of decorative elements in the external fronts. (a) Nicotra House; (b) Marano House.

\subsection{Current Energy Performances}

The energy needs of the two buildings chosen as case studies were calculated following the simplified procedure described in the Italian standard UNI/TS 11300, which is applicable in case of existing buildings:

- $Q_{H}=Q_{t}+Q_{v e}-\eta_{H g}\left(Q_{s o l}+Q_{i n t}\right)$

- $Q_{c}=Q_{s o l}+Q_{i n t}-\eta_{C, l}\left(Q_{t}+Q_{v e}\right)$

$Q_{H}$ and $Q_{C}$ are the energy used for space heating and space cooling, $Q_{t}$ and $Q_{v e}$ are the heat losses due to transmission and ventilation, $Q_{\text {sol }}$ are the solar gains penetrating through the glazed envelope and $Q_{i n t}$ are the internal gains. The heat gains are limited by the utilization factor $\eta_{H, g}$.

The thermal behaviour of masonry under dynamic boundary conditions may be characterized by means of the periodic thermal transmittance $(\mathrm{Y})$ that indicates the capability of an opaque wall to shift and attenuate thermal flux, which crosses over $24 \mathrm{~h}$. Moreover, the thermal inertia of the building envelope may also be evaluated through the dynamic factors time lag $(\phi)$ and decrement factor (f).

On this regard, the Italian legislation on the energy performance of buildings requires that vertical walls facing from East to West must have either a superficial thermal mass higher than $230 \mathrm{~kg} \mathrm{~m}^{-2}$ or a periodic thermal transmittance lower than $0.12 \mathrm{~W} / \mathrm{m}^{2} \mathrm{~K}$. Furthermore, time lag and decrement factors must comply with the data presented in Table 3.

Table 3. Rating for time shift and decrement factor, based on Italian regulation.

\begin{tabular}{ccc}
\hline Time Shift & Decrement Factor & Rating \\
\hline$\phi>12$ & $\mathrm{f}<0.15$ & Excellent \\
$12 \geq \phi>10$ & $0.15 \leq \mathrm{f}<0.30$ & Good \\
$10 \geq \phi>8$ & $0.30 \leq \mathrm{f}<0.40$ & Middle \\
$8 \geq \phi>6$ & $0.40 \leq \mathrm{f}<0.60$ & Sufficient \\
$\phi \geq 6$ & $\mathrm{f} \leq 0.60$ & Bad \\
\hline
\end{tabular}

As already mentioned, the studied buildings are located in Catania (lat. $37^{\circ} 30^{\prime}$, long $15^{\circ} 4^{\prime}$ ) a city belonging to climate zone B, according to Presidential Decree 412/93 updated to 2009 (Table 4). Besides, Catania belongs to climate zone Csa (warm and temperate climate), according to Köppen and Geiger classification [36] with an average temperature of $17.8^{\circ} \mathrm{C}$ and the yearly average rainfall of $567 \mathrm{~mm}$.

The hottest month of the year is August with an average daily temperature of $26.2^{\circ} \mathrm{C}$. January is the month with the lowest temperature of the year, with an average daily temperature of $10.7^{\circ} \mathrm{C}$. 
The building energy needs were calculated during both the winter and summer period, assuming a design temperature (Ti) by 20 and $26^{\circ} \mathrm{C}$ respectively in winter and summer periods. The outdoor temperatures assumed in the calculation are the average monthly values.

Table 4. Data referring to buildings location.

\begin{tabular}{ccccc}
\hline $\begin{array}{c}\text { Geographic } \\
\text { Location }\end{array}$ & Climatic Zone & $\begin{array}{c}\text { Heating } \\
\text { Degree Days }\end{array}$ & Heating Period & Cooling Period \\
\hline Catania & B & 833 & $\begin{array}{c}\text { 1 December- } \\
31 \text { March }\end{array}$ & $\begin{array}{c}\text { 1 April- } \\
\text { No November }\end{array}$ \\
\hline
\end{tabular}

Nicotra House and Marano House have the main façades oriented to North and East and to North respectively; and they have a Surface area to Volume ratio (S/V) of 0.48 and 0.47 (Table 5).

Table 5. Data referring to buildings.

\begin{tabular}{ccc}
\hline & Nicotra House & Marano House \\
\hline Floor area & $472.70 \mathrm{~m}^{2}$ & $725.50 \mathrm{~m}^{2}$ \\
Surface area to heated volume ratio (S/V) & $0.482 \mathrm{~m}^{-1}$ & $0.475 \mathrm{~m}^{-1}$ \\
\hline
\end{tabular}

The building energy performances were calculated using the software "Masterclima Aermec software v.1.45" that is based on a monthly-steady-state method.

The current values of the thermal transmittances $(\mathrm{U})$ of the opaque envelope are rather high, with average values of $1.41 \mathrm{~W} / \mathrm{m}^{2} \mathrm{~K}$ for Nicotra House and $1.25 \mathrm{~W} / \mathrm{m}^{2} \mathrm{~K}$ for Marano House. Such $\mathrm{U}_{\text {values }}$ are very far from the limit imposed by the current regulation, which are $0.40 \mathrm{~W} / \mathrm{m}^{2} \mathrm{Kfor}$ walls and $0.32 \mathrm{~W} / \mathrm{m}^{2} \mathrm{~K}$ for roof. The transparent vertical closures (equal to $11 \%$ compared to the surface of the casing) are characterized by U-value of $4.65 \mathrm{~W} / \mathrm{m}^{2} \mathrm{~K}$, which is also higher than the normative value $\left(3.00 \mathrm{~W} / \mathrm{m}^{2} \mathrm{~K}\right)$. Tables 6 and 7 show the thermophysical property of the opaque envelope of the buildings.

Otherwise, the time lag reaches average values of $12.9 \mathrm{~h}$ for Nicotra House and $10.67 \mathrm{~h}$ for Marano House. Such features are mainly due to the opaque vertical closures that are strongly massive with a superficial mass higher than $1000 \mathrm{~kg} \mathrm{~m}^{-2}$. Thus, the building envelopes of these buildings lead to the achievement of good performance during the summer period. Tables 8 and 9 show the current energy performances of the buildings.

Table 6. Thermophysical properties of opaque envelope (Nicotra House).

\begin{tabular}{ccccccc}
\hline & Thickness $(\mathbf{m})$ & $\mathbf{M}\left(\mathbf{K g} / \mathbf{m}^{2}\right)$ & $\mathbf{U}\left(\mathbf{W} / \mathbf{m}^{2} \mathbf{K}\right)$ & $\mathbf{Y}\left(\mathbf{W} / \mathbf{m}^{2} \mathbf{K}\right)$ & Time Lag $(\mathbf{h})$ & Decrement Factor \\
\hline Wall & 0.80 & 1817 & 1.38 & 0.025 & +21.15 & 0.018 \\
\hline
\end{tabular}

Table 7. Thermophysical properties of opaque envelope (Marano House).

\begin{tabular}{ccccccc}
\hline & Thickness $(\mathbf{m})$ & $\mathbf{M}\left(\mathbf{K g} / \mathbf{m}^{2}\right)$ & $\mathbf{U}\left(\mathbf{W} / \mathbf{m}^{2} \mathbf{K}\right)$ & $\mathbf{Y}\left(\mathbf{W} / \mathbf{m}^{2} \mathbf{K}\right)$ & Time Lag $(\mathbf{h})$ & Decrement Factor \\
\hline Wall & 0.60 & 1373 & 1.67 & 0.092 & +16.30 & 0.055 \\
\hline
\end{tabular}

Table 8. Current energy performances (Nicotra House).

\begin{tabular}{cccccc}
\hline & $Q_{t} / \mathbf{S}_{\mathbf{u}}\left(\mathbf{k W h} / \mathbf{m}^{2}\right)$ & $Q_{v e} / \mathbf{S}_{\mathbf{u}}\left(\mathbf{k W h} / \mathbf{m}^{2}\right)$ & $Q_{\text {sol }} / \mathbf{S}_{\mathbf{u}}\left(\mathbf{k W h} / \mathbf{m}^{2}\right)$ & $\begin{array}{c}E P_{H, \text { inv }} \\
\left(\mathbf{k W h} / \mathbf{m}^{2} \text { year }\right)\end{array}$ & $\begin{array}{c}E P_{C, \text { inv }} \\
\left(\mathbf{k W h} / \mathbf{m}^{2} \mathbf{y e a r}\right)\end{array}$ \\
\hline heating & 90.11 & 12.71 & 11.29 & 85.88 & - \\
cooling & 38.32 & 5.06 & 48.11 & - & 24.31 \\
\hline
\end{tabular}


Table 9. Current energy performances (Marano House).

\begin{tabular}{lccccc}
\hline & $Q_{t} / \mathbf{S}_{\mathbf{u}}\left(\mathbf{k W h} / \mathbf{m}^{2}\right)$ & $Q_{v e} / \mathbf{S}_{\mathbf{u}}\left(\mathbf{k W h} / \mathbf{m}^{2}\right)$ & $Q_{\text {sol }} / \mathbf{S}_{\mathbf{u}}\left(\mathbf{k W h} / \mathbf{m}^{2}\right)$ & $\begin{array}{c}E P_{H, i n v} \\
\left(\mathbf{k W h} / \mathbf{m}^{2} \text { year }\right)\end{array}$ & $\begin{array}{c}E P_{C, \text { inv }} \\
\mathbf{( k W h} / \mathbf{m}^{2} \text { year) }\end{array}$ \\
\hline heating & 82.97 & 14.76 & 22.09 & 71.41 & - \\
cooling & 46.96 & 8.35 & 82.93 & - & 44.25 \\
\hline
\end{tabular}

Here, the primary energy for heating the building envelope $\left(E P_{H, i n v}\right)$ and the primary energy for cooling the building envelope $\left(E P_{C, \text { inv }}\right)$ are defined as:

- $\quad E P_{H, i n v}=\frac{Q_{H}}{S_{u}}$

- $\quad E P_{C, i n v}=\frac{Q_{C}}{S_{u}}$

As for the ventilation rate, considering the permeability of the masonries the value of 0.5 volume/hour, (i.e., natural ventilation) has been assumed.

The actual energy demand for space heating is of $85.88 \mathrm{kWhm}^{-2}$ per year (Nicotra House) and $71.41 \mathrm{kWhm}^{-2}$ per year (Marano House). These modest performances can be also related with the not optimal exposure of the building main façades, that are North and East for Nicotra House and North for Marano House. Consequently, the solar gains are rather low, resulting in $11.29 \mathrm{kWhm}^{-2}$ for Nicotra House and $22.09 \mathrm{kWhm}^{-2}$ for Marano House.

Otherwise, the energy needs for space cooling are quite low, resulting in $24.31 \mathrm{kWhm}^{-2}$ per year for Nicotra House and $44.25 \mathrm{kWhm}^{-2}$ per year for Marano House.

\subsection{Seismic Vulnerability: Hypothetical Damage Scenarios}

Referring to the abacuses of damage mechanisms, according to the analysis of the geometric and technical-constructive characteristics of the present case studies, we can carry out some qualitative considerations on the seismic vulnerability of the building for indispensable and adequate seismic improvement actions [37].

Assuming there is a good-quality masonry, the most vulnerable area of Nicotra House is represented by the west side on via Grotte Bianche and the corner. On the eastern front, in absence of effective constraints in the head of the wall at the third-floor terrace, a composed overturning of the façade could be activated; there could be a rigid rotation of the entire wall panel or its portion and the consequent dragging part of the north façade wall. This dragging involves, indeed, a variable wedge-shaped detachment depending on the presence of inter-floor reinforced concrete curbs or stiffening of floors in NP iron profiles (Figure 12a). Alternatively, if there were no linking devices between the walls and at the floors, a simple overturning of the whole eastern front could occur, with the formation of a horizontal hinge at the base of the wall panel (Figure 12b). As already mentioned, the central part has a recently created summit curb. Theoretically, the curb should carry out a circling action to guarantee the box-like behaviour of the building and counteract the thrusts on the perimeter walls by the rafters. Despite this, this device is made of reinforced concrete and introduces a very high stiffness in the building compared to that of the underlying masonry. In this way, horizontal cracks could be generated at the interface between the curb and the masonry, with dangerous sliding and disruption of the apical parts and consequent collapse of the underlying wall panels. 


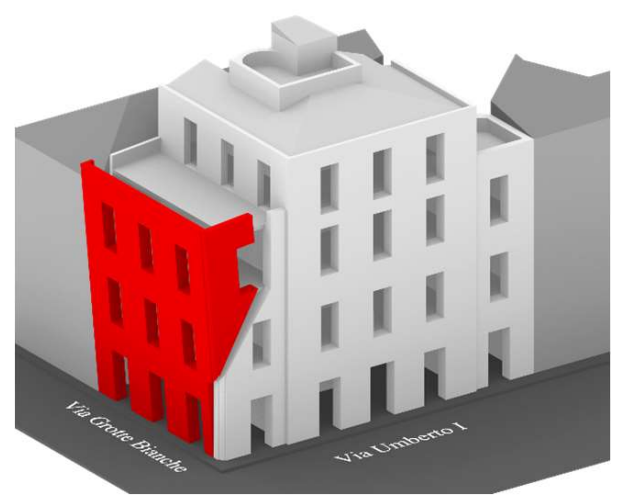

(a)

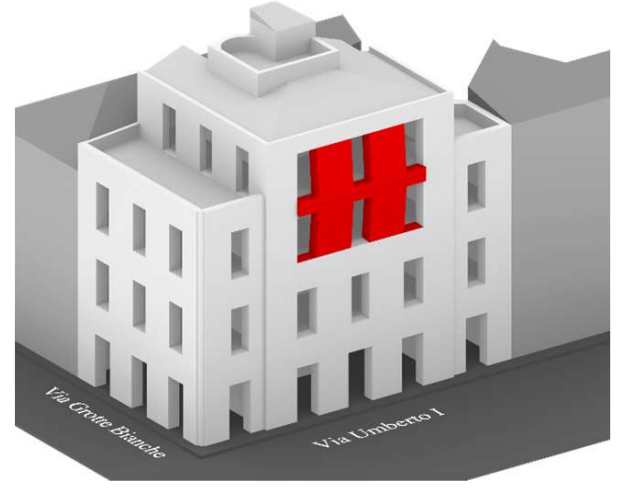

(c)

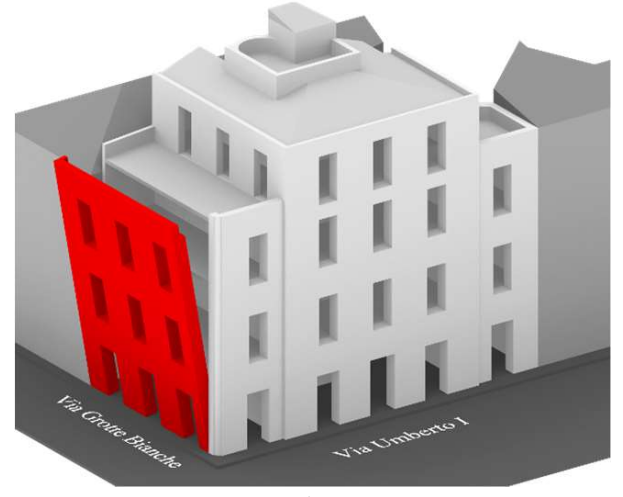

(b)

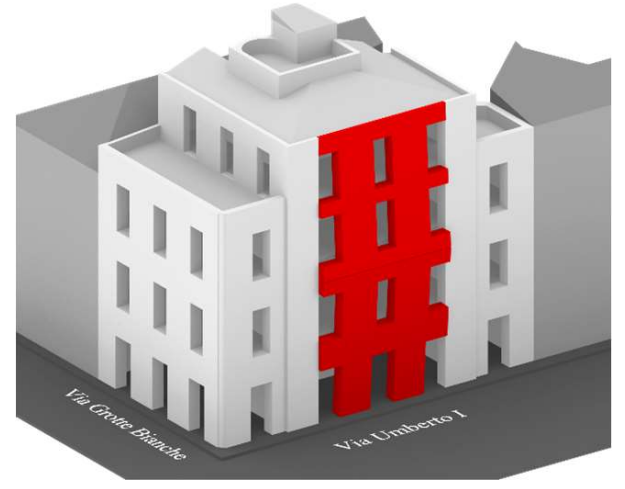

(d)

Figure 12. Possible damage mechanisms in Nicotra House: (a) composed overturning; (b) simple overturning; (c,d) vertical bendings.

The central part of the northern front, constrained at the foundation and superiorly through the curb, may be subjected to vertical bending mechanisms, especially if the connections with the orthogonal walls and the floors are ineffective. In correspondence with the constraints, a horizontal cylindrical hinge is formed and it divides the central area of the wall into two parts that can thus rotate. The damage mechanism will manifest itself through a swelling of the wall face in the middle area and a series of vertical and horizontal cracks near the openings (Figure 12c,d).

The geometric and technical-constructive characteristics of Marano House lead us to suppose possible phenomena of the overturning of the main front. Indeed, the façade does not have constraints in the upper part; we must also consider both the weakly pushing action due to the pavilion vault of the second floor and the secondary structure of the roof both the thrusts that could be generated by the iron beams of the intermediate floors in case of an earthquake.

Because of these actions, a simple overturning of the front could be activated; this overturning would involve either the whole façade (with horizontal cylindrical hinge placed at the "rez de chaussée"), if the connections with the orthogonal walls and the floors are ineffective (Figure 13a), or only a portion in the presence of stiffened intermediate floors (Figure 13b). 


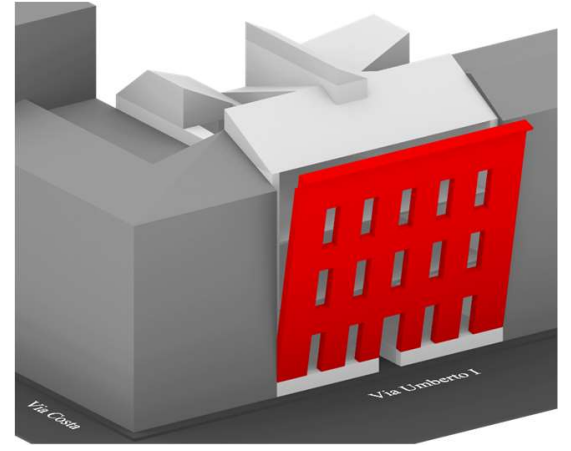

(a)

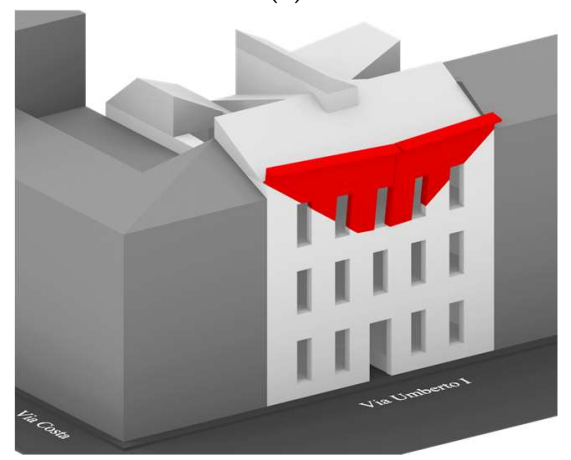

(c)

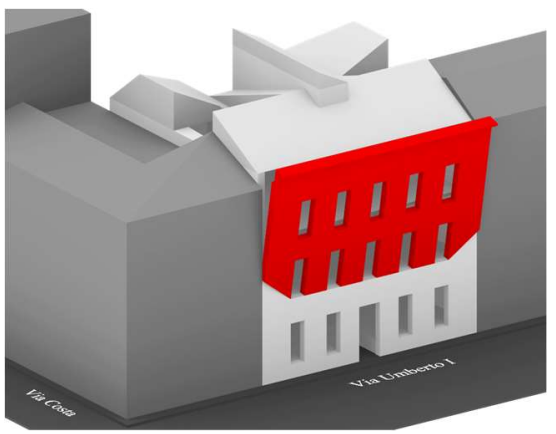

(b)

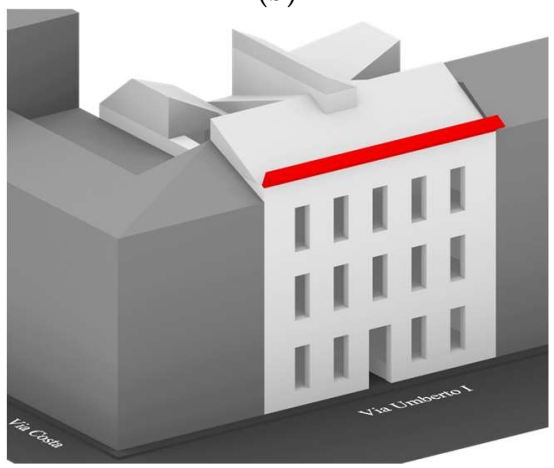

(d)

Figure 13. Possible damage mechanisms in Marano House: (a,b) simple overturning; (c) horizontal bending; (d) overturning of the cornice.

If there were effective linking devices between the façade and the orthogonal walls, the horizontal thrusts, due to the absence of summit constraints, could activate an "arc effect" of the wall in the horizontal plane (horizontal bending) with wedges of detachment and oblique cylindrical hinges on the sides and vertical cylindrical hinges in the centre. (Figure 13c) [37].

The artistic and rounded summit cornice of Marano House has a thin wall thickness; it could overturn with horizontal cylindrical hinge (Figure 13d).

The horizontal thrusts also cause coplanar shear stresses of the masonry, called "second mode" mechanisms. These thrusts can also be caused by hammering between adjacent buildings if not well connected; this often leads to the appearance of broken breaks in the wall panels between the openings with diagonal or x-shaped cracks. In the external fronts of Nicotra House and Marano House, the second mode mechanisms would transform the cracks into real preferential ways of triggering of out-of-plane mechanisms and would expose projections and ornaments in limestone to notable risk. Shelves, slabs of balconies, frames and friezes, especially if not well linked to the support, can be overturned even under the influence of minor earthquakes, with obvious risk both for public safety and for the protection and conservation of historical-artistic settings.

\subsection{Meta-Design}

\subsubsection{Suggestions for Energy Refurbishment}

From the evaluation of the current energy performance, it has been pointed out that the building does not perform well in winter because of two main reasons: an exposure of the main façades that is not optimal and the high U-values of the building envelope, particularly the opaque and transparent vertical closures.

If we consider the summer season, instead, the time lag associated with the night-time ventilation could mitigate the effects of thermal forcing. 
The buildings characterize the architecture of the late nineteenth century in Catania; the external plasters have to be protected because the volcanic aggregate that determines their peculiar colour cannot be extracted anymore. Therefore, as mentioned in the Introduction section, the principle of conservation of material integrity must govern any design strategy. According to this perspective, the data provided by this pre-diagnosis lead to the meta-design, that is, the addresses for the future refurbishment. The following designs suggestions should be considered:

- thermal insulation of terraces and vaults or floor (inside the attic);

- recovery of the traditional wooden windows;

- thermal plasters in the secondary façades facing the cloister (because they only partially show the original plaster);

It should be noted that in the choice of design actions, especially in the roof and about the thermal plaster, the ratio between increases in thicknesses and the contribution offered to improve performance was assessed; moreover, it has been concluded that each of the interventions offers a minimal contribution to the improvement of energy demands.

Regarding the attic and the terraces, it was decided to use an insulation with glass wool $\left(\lambda=0.035 \mathrm{~W} \mathrm{~m}^{-1} \mathrm{~K}^{-1}\right.$ and thickness of $\left.6.0 \mathrm{~cm}\right)$ on the outer side of the vaults and with expanded perlite $\left(\lambda=0.052 \mathrm{Wm}^{-1} \mathrm{~K}^{-1}\right.$ and thickness of $\left.6.0 \mathrm{~cm}\right)$. The $\mathrm{U}$-value is equal to an average of $0.47 \mathrm{Wm}^{2} \mathrm{~K}^{-1}$ and $0.44 \mathrm{Wm}^{2} \mathrm{~K}^{-1}$. About the windows it was decided to replace the existing glass with a glazing (4-6-4 mm) separated by an air gap in order to reach a U-value of $3.0 \mathrm{Wm}^{2} \mathrm{~K}^{-1}$; this entailed only a minimal integration necessary for the setting of the new glazing in the casing.

Considering all the energy refurbishments, we obtained the results showed in Table 10. We observe that in Nicotra House there is a reduction in the energy demand of $20.84 \%$ in winter $\left(67.98 \mathrm{kWhm}^{-2}\right.$ per year) and of $17.44 \%$ in summer $\left(20.07 \mathrm{kWhm}^{-2}\right.$ per year) is achieved. Instead, for Marano House more appreciable results were obtained because the largest dispersing surface is in the attic that is not subject to constraint. The improvement of the energy performance of these buildings can be considered a reasonable success considering that the summer season is the most problematic in the Mediterranean climate and that the interventions are minimal and reversible.

Table 10. Comparison of energy requirements $\left(\mathrm{kWh} / \mathrm{m}^{2}\right.$ per year) after the improvements.

\begin{tabular}{ccccc}
\hline & \multicolumn{2}{c}{ Nicotra House } & \multicolumn{2}{c}{ Marano House } \\
\cline { 2 - 5 } & $\mathbf{E P}_{\mathbf{H , i n v}}$ & $\mathbf{E P}_{\mathbf{C}, \text { inv }}$ & $\mathbf{E P}_{\mathbf{H}, \text { inv }}$ & $\mathbf{E P}_{\mathbf{C}, \text { inv }}$ \\
\hline As built & 85.88 & 24.31 & 71.41 & 44.25 \\
After & 67.98 & 20.07 & 43.93 & 26.83 \\
\hline
\end{tabular}

Moreover, the reduction of energy demand, evaluated with steady-state simulation, are interesting considering that they may be obtained through routinely and reversible actions that do not disturb the residents. We also believe this is a good result for the summer season, considering that Catania belongs to the most severe summer climate zone, according to the ENEA-MiSE research report [11]. Today, climate change is transforming the relationship between building and its environment: we have shorter and colder winters and warmer summers and for a longer period. Therefore, especially in the Mediterranean climate area, we must pay more attention to the energy performances for summer air conditioning. In this way, the massive buildings have a value that is the high thermal inertia; this allows us to maintain an indoor comfort in the absence of a thermal insulation of the vertical opaque closures, as required by law. Therefore, thermal inertia is an important opportunity to also reduce the consumption of materials and embodied energy, if we consider any design strategy according to an LCA approach [38].

This study is a good starting point to consider the limit as a resource to pursue environmental and cultural sustainability. It should be completed with a dynamic simulation to evaluate internal 
comfort and with an in-situ survey of thermal transmittance; this is because, according to research conducted, the real transmittance is lower than the calculated value. However, the effective result of improvement, achieved with minimum work (reversible, with recyclable materials and characterized by constructive processes at low environmental impact), would be advantageous if it were extended to all historical buildings and if it also included the tax relief provided by current national policies.

\subsubsection{Suggestions for Seismic Refurbishment}

After the qualitative prediction of possible damage scenarios, an appropriate instrumental investigation campaign must necessarily follow in order to verify the existence or lack thereof of connections between the various building elements and suitable kinematic analyses of the wall panels to identify the most probable damage mechanisms.

The anamnesis conducted in Nicotra and Marano Houses would seem to show a good quality of the construction techniques adopted; this allowed the buildings to resist seismic stresses over the course of the last century. However, due to the aforementioned critical issues, seismic improvement works would be needed; these design suggestions must combine the demands of conservation with those of public safety in the case of significant seismic events such as those that occurred in Central Italy in 2016. In agreement with Giuffrè's theories [39] and with his empirical approaches, now widely shared, these design actions must be aimed to correct original construction defects and tampering, leading the structural composition of the "corpus" to the "good rules of the art".

Trying to always follow a constructive lexicon of coherent and compatible actions with the original one [39], to avoid the dreaded overturning of the façades, it will be necessary to improve the box-like behaviour in both examined cases. The connection should be ensured at the cantonal and in the orthogonal walls. This could be achieved through the installation of tie rods at the level of intermediate floors (also in the terrace roof of Nicotra House); these ties will connect the walls to the transversal ones and they will also contrast the thrust of the cross vaults of the ground floor. The connections between floors and walls must be verified; the walls with inner vulnerabilities (due, for example, to the decohesion of the mortar) should be consolidated and the wall portions in correspondence with the anchor plates must be strengthened to avoid the puncturing of the masonry.

In Nicotra House, however, it should be necessary to ensure that the rafters are bound to the longitudinal reinforcement of the curb. Any replacement of the existing curb with a more compatible reinforced masonry, such as A. Giuffrè suggests [39,40], must be evaluated towards the timing and costs that such an invasive intervention would entail.

In Marano House, it should be necessary to avoid the overturning of the upper part, considering however the high historic and artistic value of the decorated cornice.

The analysis of possible damage mechanisms highlights the effective need to design effective anti-seismic devices. The qualitative prefigured scenario is essential prerequisite for an accurate setting of the anti-seismic improvement design. Taking account of possible damage mechanisms, the designer will be able to identify the mechanism with more possibilities of activation by calculating the kinematics and finding a "collapse multiplier" which firstly causes the out-of-plane instability [40]. Therefore, the design actions will be aimed at preventing that mechanism.

Furthermore, the study shows the greater seismic vulnerability of Nicotra House compared to Marano House. This is also true in case of "second mode" mechanisms, due to the corner position of Nicotra House. Indeed, if we consider the façades of any historic urban block, if there are coplanar seismic actions and there are no differential settlements, the interlocked buildings exert a reciprocal containment action that exposes them less to seismic stress on the plane. As shown by A. Giuffrè, straight lines of 45 degrees ("critical lines"), drawn from the extreme points of the block, identify wall portions of corner buildings without containment actions ("wedge of detachment"); in these parts, more important cracks and the overturning of façade portions will appear. Moreover, these lines identify an ideal arc below which the overturnings are less likely; this is because every building 
in a landlocked plot, like Marano House, will benefit from the containment actions of the adjacent buildings (Figure 14) [40].

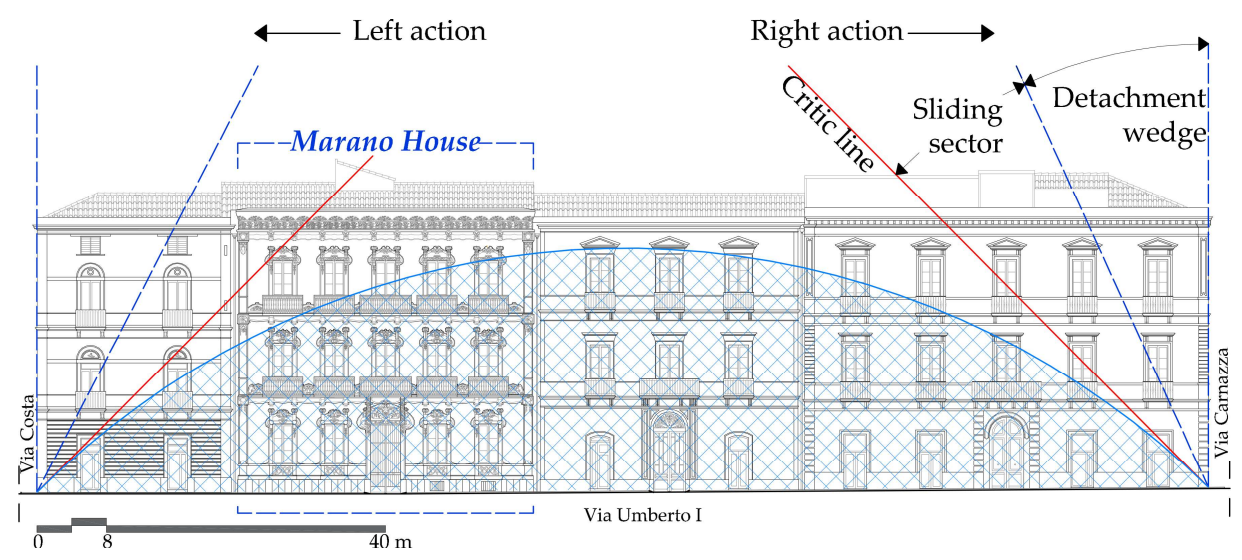

Figure 14. Resistant mechanisms of Marano House urban block [32].

The surveys and the analyses carried out during the cognitive phase, gave us the opportunity to identify the possible seismic vulnerabilities of Nicotra House and Marano House. The proposed design techniques follow the guidelines of the efficiency of the good "standard"; the traditional building techniques, if improved, certainly meet the requirements of compatibility and minimum action. These requirements are considered indispensable when we work on historic architecture. According to Giuffrè, the seismic improvement design, aimed at restoring the structural behaviour of the masonry buildings to the standard, represents "not a sentimental issue but instead, it comes from the cultural need to preserve the historical choices contained in the works of our past" [39].

In urban areas, these issues become more complex because we must also consider the structural co-participation of adjacent buildings; in fact, the concept of urban vulnerability as a summation of single vulnerabilities of the buildings has now been overcome. The building scale is too small to understand the relationships in the urban fabric between adjacent buildings [41]. Therefore, the cognitive investigations should take place at two different scales: at the aggregate scale, first and at the building unit scale, after, as a specific approach for the assessment of seismic safety in the historic centres at several levels of knowledge (LV1-LV2-LV3) [19].

\section{Discussion}

Historic buildings adopt traditional techniques, specific to each geographical area and represent an open system that interacts with the environment. The cultural value is a constraint to the adoption of the usual refurbishment techniques for the built heritage starting from the second half of the twentieth century [42]. The guidelines for energy efficiency and evaluation and mitigation of the seismic risk of cultural heritage identify two specific paths with a starting point for a cognitive phase about historical, typological, morphological and technological aspects. In fact, historical buildings are often characterized by successive constructive transformations, so it is necessary to work "case by case" with the specific competence of the architect, with which the specialists must necessarily consult. However, the whole methodological process should be followed not according to a linear approach but according to a systemic approach, relating the levels of the building description.

We have chosen to investigate the cognitive process up to the pre-diagnostic phase (supported by qualitative analyses), because from this descend the disciplinary investigations that will lead to the energy and structural diagnosis; we have proposed a method that integrates the qualitative knowledge levels, specific for both aspects (energy and seismic). 
According to this approach, we have studied two historic buildings, which are similar for building age and characterized by different positions within the urban fabric and therefore with different energy performances and seismic behaviour.

The application of the cited method (Figure 3) allows us to make the following considerations. The general knowledge phase (Phase A) is an important starting platform because it allows us to define the cultural value, the current geometric-spatial configuration but also, the construction events, the eventual typological evolution and any eventual instabilities or decays.

Inevitably, the next phase involves a breakdown operation, in which each disciplinary competence will operate for successive degrees of study; in particular, through the simplified methods (Phases B1 and B2) we can be able to define the pre-diagnosis (Phase C) and the meta-design (Phase D). The meta-design will be characterized by addresses for energy and seismic aspects. Moreover, the pre-diagnosis sets the bases for the definition of any ND tests (Phase E) and/or the use of detailed calculation methods.

According to the results obtained with the steady-state method, for both buildings it is possible to obtain a fair reduction of energy requirements with minimal actions. Despite this, as these are massive buildings, it will be necessary to complete the study through dynamic simulation method aimed at assessing the comfort, on-site surveys of thermal transmittance and/or survey of indoor microclimate. The energy manager will decide what should be studied in deep.

Instead, regarding the empirical method for the qualitative seismic vulnerability assessment, numerical modelling is always necessary in the subsequent phases.

The outcome of the cognitive phase must be reported in the "Building dossier," a document provided by the Italian regulations currently being approved. According to proposal, this dossier will be elaborated in three sequential chapters corresponding to the main phases of the cognitive process (Figure 3); the first one developed by the architect during Phase A; the second elaborated by specialists in the pre-diagnostic phase (Phase C); finally, the third will report the results of the diagnosis (Phase F). Specifically, the first chapter is very important because it allows us to save time and costs; indeed, energy manager and structural designer would have at their disposal a starting knowledge base to be implemented in order to elaborate first the pre-diagnosis and then the diagnosis. In this way, we would be able to involve one of the stakeholders, that is, the owners of the buildings, with greater incisiveness. These dossiers, designed for subsequent processing and containing different disciplinary contributions, will also allow us to pursue a process quality.

Finally, the perspective of an integrated approach for a historic building takes on a particular complexity; this because the energetic and structural performances are closely linked to knowledge of the typological, morphological and technological aspects and to the construction events. For this reason, it is important to have at disposal a common methodology to which the disciplinary contributions must refer. Within this, it will be necessary to provide specialized analysis and choral synthesis steps coordinated by the designer architect. The explored pre-diagnostic process allowed us to evaluate and to manage the complexity of this approach; future developments will concern the assessment of the following phases, to quantitatively evaluate the energy and seismic performances of the two cases studied.

Author Contributions: A.M. (Angela Moschella) designed the research and wrote the introduction, A.G. conducted energy simulation, A.M. (Attilio Mondello) studied the damage mechanism through empirical methods and G.S. dealt with the relationships among cultural, seismic and energy aspects and she defined the seismic meta-design; A.L.F. studied the buildings from constructive point of view; A.S. reviewed the paper. All the authors contributed equally to the Materials and Methods and Discussion sections.

Funding: The research was partially funded by "Progetti di Ricerca di Interesse Nazionale (PRIN 2009): Metodologie innovative per la riqualificazione energetica e il recupero prestazionale del patrimonio edilizio esistente strutturato in geocluster" (National Coordinator: Emilio Pizzi). The research was also partially funded by PO FESR SICILIA 2007-2013, "Progetto RILTUS."

Conflicts of Interest: The authors declare no conflict of interest. 


\section{References}

1. Salemi, A.; Patania, F.; Cascone, S.; Gagliano, A.; Lo Faro, A.; Lombardo, G.; Moschella, A.; Sapienza, V. Thermal performance of existing buildings in mediterranean climate area. In Changing Needs, Adaptive Buildings, Smart Cities; Ural, O., Pizzi, E., Croce, S., Eds.; PoliScript: Milano, Italy, 2013; Volume 1, pp. 1017-1024, ISBN 9788864930138.

2. UNI/TS 11300-1. In Prestazioni Energetiche Degli Edifici Parte 1: Determinazione del Fabbisogno di Energia Termica Dell'Edificio per la Climatizzazione Estiva ed Invernale; Ente Italiano di Normazione: Milan, Italy, 2014. (In Italian)

3. Adhikari, R.S.; Lucchi, E.; Pracchi, V. Experimental measurements on thermal transmittance of the opaque vertical walls in the historical buildings. In Proceedings of the 28th International PLEA Conference: Opportunities, Limits \& Needs Towards an Environmentally Responsible Architecture, Lima, Perù, 7-9 November 2012.

4. Baker, P. U-values and traditional buildings. In Situ Measurements and Their Comparison to Calculated Values, Historic Scotland Technical Paper 10; Glasgow Caledonian University: Glasgow, UK, 2011; Available online: https:/ /goo.gl/ST4pt8 (accessed on 25 May 2018).

5. Lucchi, E. Thermal transmittance of historical stone masonries: A comparison among standard, calculated and measured data. Energy Build. 2017, 151, 393-405. [CrossRef]

6. Nardi, I.; De Rubeis, T.; Taddei, M.; Ambrosini, D.; Sfarra, S. The energy efficiency challenge for a historical building undergone to seismic and energy refurbishment. Energy Procedia 2017, 133, 231-242. [CrossRef]

7. Zeno, B.; Troi, A. Energy Efficiency Solutions for Historic Buildings. A Handbook; BirkhaÅNuser Verlag GmbH: Basel, Switzerland, 2015; ISBN 9783038216506.

8. Evola, G.; Marletta, L.; Patanè, E.M.; Natarajan, S. Thermal inertia of heavyweight traditional buildings: Experimental measurements and simulated scenarios. Energy Procedia 2017, 133, 42-52. [CrossRef]

9. Gagliano, A.; Nocera, F.; Patania, F.; Moschella, A.; Detommaso, M.; Evola, G. Synergic effects of thermal mass and natural ventilation on the thermal behaviour of traditional massive buildings. Int. J. Sustain. Energy 2016, 35, 411-428. [CrossRef]

10. Stazi, F. Thermal Inertia in Energy Efficient Building Envelopes; Butterworth Heinemann, Elsevier: Oxford, UK, 2017; ISBN 9780128139707.

11. Terrinoni, L.; Signoretti, P.; Iatauro, D. Definizioni Delle Zone Climatiche Estive e Della Durata Della Stagione di Climatizzazione Estiva per Gli Edifici Residenziali nel Territorio Italiano Attraverso La Metodologia Dell'Indice di Severità Climatica ENEA. Report RdS/PAR2013/129. September 2014. Available online: https:/ / goo.gl/xrfdhW (accessed on 11 May 2018).

12. Ferrari, S. Procedure di calcolo semplificate e valutazioni dinamiche. Costr. Laterizio 2009, 131, 60-63.

13. Battisti, A. Guidelines for energy efficiency in the cultural heritage. TECHNE-J. Technol. Archit. Environ. 2016, 12, 65-73. [CrossRef]

14. MIBAC (Ministry of Heritage and Cultural Activities and Tourism). Linee di Indirizzo per il Miglioramento Dell'Efficienza Energetica nel Patrimonio Culturale Architettura, Centri e Nuclei Storici ed Urbani, Rome, 2015. Available online: https:/ / goo.gl/oCw7NP (accessed on 11 May 2018).

15. Giuffré, A. Letture Sulla Meccanica Delle Murature Storiche; Kappa: Rome, Italy, 1991; ISBN 9788865142301.

16. Di Pasquale, S. L'arte del Costruire. Tra Conoscenza e Scienza; Marsilio: Venice, Italy, 2003; ISBN 9788831763523.

17. Doglioni, F.; Moretti, A.; Petrini, V. Le Chiese e il Terremoto; LINT: Trieste, Italy, 1994; ISBN 8886179367.

18. Della Torre, S. Terremoto e prevenzione. Ananke 2016, 79, 5-8.

19. Direttiva del Presidente del Consiglio dei Ministri del 9 febbraio 2011: Valutazione e Riduzione del Rischio Sismico del Patrimonio Culturale Con Riferimento Alle Norme Tecniche per Le Costruzioni di Cui al Decreto del Ministero Delle Infrastrutture e dei Trasporti del 14 gennaio 2008. G.U. n. 47 del 26/2/2011 S.O. n. 54. Available online: https:/ / goo.gl/8ypKkE (accessed on 11 May 2018).

20. Blasi, C. Sicurezza e responsabilità: Due termini da ripensare alla luce delle norme vigenti per la salvaguardia degli edifici storici. Boll. Ing. 2014, 6, 5-10. Available online: https://goo.gl/W6Sw1k (accessed on 11 May 2018).

21. Blasi, C. Architettura Storica e Terremoti. Protocolli Operativi per la Conoscenza e la Tutela; Wolters Kluwer Italia: Milanofiori Assago, Italy, 2013; ISBN 8867501526. 
22. Ascione, F.; Bianco, N.; De Masi, R.F.; Mauro, G.M.; Vanoli, G.P. Cost-Effective Refurbishment of Italian Historic Buildings. In Cost-Effective Energy Efficient Building Retrofitting, 1st ed.; Pacheco-Torgal, F., Granqvist, C., Jelle, B., Vanoli, G., Bianco, N., Kurnitski, J., Eds.; Woodhead Publishing: Cambridge, UK, 2017; pp. 553-600, ISBN 9780081011287.

23. Ascione, F.; Ceroni, F.; De Masi, R.F.; de' Rossi, F.; Pecce, M.R. Historical buildings: Multidisciplinary approach to structural/energy diagnosis and performance assessment. Appl. Energy 2017, 185, 1517-1528. [CrossRef]

24. Ferrante, A.; Mochi, G.; Predari, G.; Badini, L.; Fotopoulou, A.; Gulli, R.; Semprini, G. A European Project for Safer and Energy Efficient Buildings: Pro-GET-onE (Proactive Synergy of inteGrated Efficient Technologies on Buildings' Envelopes). Sustainability 2018, 10, 812. [CrossRef]

25. Georgescu, E.; Georgescu, M.; Macri, Z.; Marino, E.; Margani, G.; Meita, V.; Pana, R.; Cascone, S.; Petran, H.; Rossi, P.P.; et al. Seismic and Energy Renovation: A Review of the Code Requirements and Solutions in Italy and Romania. Sustainability 2018, 10, 1561. [CrossRef]

26. Basiricò, T.; Enea, D. Seismic and Energy Retrofit of the Historic Urban Fabric of Enna (Italy). Sustainability 2018, 10, 1138. [CrossRef]

27. Dalla Mora, T.; Pinamonti, M.; Teso, L.; Boscato, G.; Peron, F.; Romagnoni, P. Renovation of a School Building: Energy Retrofit and Seismic Upgrade in a School Building in Motta Di Livenza. Sustainability 2018, 10, 969. [CrossRef]

28. Moschella, A.; Sanfilippo, G. Il requisito di sostenibilità nel progetto di riuso degli edifici storici. Il Progetto Sostenibile 2016, 38, 38-47.

29. De Santoli, L. Guidelines on energy efficiency of cultural heritage. Energy Build. 2015, 86, 534-540. [CrossRef]

30. Carbonara, G. Energy efficiency as a protection tool. Energy Build. 2015, 95, 9-12. [CrossRef]

31. Dato Toscano, Z. Il progetto di modificazione nelle abitazioni di Carlo Sada. In I Disegni del Fondo Sada Delle Biblioteche Riunite Civica e A. Ursino Recupero di Catania, II; Salmeri, M., Dato Toscano, Z., Imbrosciano, F., Rodonò, U., Eds.; Soprintendenza per i Beni Culturali e Ambientali: Catania, Italy, 1996; pp. 17-25.

32. Quartarone, C.; Sessa, E.; Mauro, E. Arte e Architettura Liberty in Sicilia; Grafil: Palermo, Italy, 2008; ISBN 9788882073244.

33. Damigella, A.M. Il contributo di Tommaso Malerba all'architettura liberty a Catania (1907-1915). Arte e Documento 2007, 23, 240-253.

34. Caniggia, C.; Maffei, G.L. Architectural Composition and Building Typology: Interpreting Basic Building; Alinea Editrice: Firenze, Italy, 2001; ISBN 8881254263.

35. Salemi, A.; Chisari, W.; Lo Faro, A.; Moschella, A.; Napoleone, A.; Sanfilippo, G. The facade Requalification of Catania Historical Centre: Materials, Buildings Elements and Urban Image. In Sustainable Housing Design. Emphasizing Urban Housing; Ural, O., Iovino, R., Frattari, A., Fascia, F., Albatici, R., Eds.; Luciano: Napoli, Italy, 2006; ISBN 9788860260307.

36. Köppen Climate Classification. Available online: https://www.britannica.com/science/Koppen-climateclassification (accessed on 11 May 2018).

37. Milano, L.; Mannella, A.; Morisi, C.; Martinelli, A. Schede illustrative dei principali meccanismi di collasso locali negli edifici esistenti in muratura e dei relativi modelli cinematici di analisi. In Allegato alle Linee Guida per La Riparazione e il Rafforzamento di Elementi Strutturali, Tamponature e Partizioni; The Laboratories University Network of Seismic Engineering and Civil Protection Department: Rome, Italy, 2009; Available online: https:/ /goo.gl/YEXAcw (accessed on 12 May 2018).

38. Moschella, A. Il Costruito Storico Nell'Epoca Della Responsabilità Ambientale. Riflessioni Sulla Riqualificazione Energetica; Bonanno Editore: Acireale-Roma, Italy, 2013; ISBN 9788896950692.

39. Giuffrè, A. Sicurezza e Conservazione dei Centri Storici, Il Caso Ortigia; Laterza: Bari, Italy, 1993; ISBN 8842042501.

40. Giuffrè, A.; Carocci, C. Codice di Pratica per La Sicurezza e La Conservazione del Centro storico di Palermo; Editore Laterza: Roma, Italy, 1999; ISBN 9788842056874. 
41. Indelicato, D. Valutazione e Riduzione Della Vulnerabilità Sismica Degli Aggregati Edilizi nei Centri Storici, Il Caso di Villa Sant'Angelo, Tesi di Dottorato di Ricerca in Progetto e Recupero Architettonico, Urbano e Ambientale, XXIII Ciclo; Università degli Studi di Catania: Catania, Italy, 2010.

42. Pracchi, V. In equilibrio tra "soppesare" e misurare. Alcune riflessioni su sostenibilità ed efficienza energetica nell'edilizia storica. Materiali e Strutture-Problemi di Conservazione 2017, 11, 67-82.

(C) 2018 by the authors. Licensee MDPI, Basel, Switzerland. This article is an open access article distributed under the terms and conditions of the Creative Commons Attribution (CC BY) license (http://creativecommons.org/licenses/by/4.0/). 